\title{
ESTUDO DA ASSOCIAÇÃO ENTRE O ISOLAMENTO DE Candida albicans E A DETECÇÃO DO VÍRUS DA LEUCOSE FELINA (FeLV) EM GATOS DA REGIÃO DA GRANDE PORTO ALEGRE*
}

\author{
JOÃO PESSOA RIOGRANDENSE MOREIRA JUNIOR
}

\author{
Laerte Ferreiro ( Orientador - UFRGS)
}

Banca Examinadora:

Luiz Carlos Severo UFRGS

Mario C. A. Meireles UFPel

Sydney Hartz Alves UFSM

A Candida albicans é uma levedura considerada habitante normal do trato intestinal de muitos mamíferos e aves. É raro ocorrer o isolamento da mesma na pele de animais saudáveis, contudo uma baixa da resistência do sistema imune induzida por exemplo, pelo vírus da leucose felina (FeLV), pode favorecer o seu desenvolvimento. Com o objetivo de estudar a possibilidade da existência de associação entre a presença de Candida albicans e a deteç̧ão do FeLV e de alguns parâmetros, foram obtidas amostras da mucosa bucal, anal, pele e sangue de 150 gatos da região da grande Porto Alegre. As amostras das mucosas e da pele foram cultivadas em ágar Sabouraud dextrose acrescido de cloranfenicol e a identificação dos isolados feita com base nos aspectos macro e microscópicos (produção de tubos germinativos e de clamidósporos). $\mathrm{O}$ único fungo encontrado foi a Candida albicans, ocorrendo em $8,7 \%$ das amostras da mucosa bucal, $6,7 \%$ da pele e de $1,3 \%$ da mucosa anal. Com as amostras de sangue foram realizados testes de imunofluorescência indireta (IFI) para detecção do FeLV, sendo trinta e sete $(24,7 \%)$ dos gatos positivos. Através do teste Qui-quadrado investigouse a possibilidade da associação entre o isolamento de Candida albicans com a detecção do FeLV, bem como com o uso prévio de medicamentos (antimicrobianos e corticosteróides), idade, sexo, raça, habitat, lesões e sintomatologia. Da mesma forma, pesquisou-se a possibilidade de existir uma associação do FeLV com as mesmas variáveis. Houve associação significativa entre os gatos FeLV positivos com maior isolamento da Candida albicans, assim como entre animais que receberam antimicrobianos e corticosteróides nos 60 dias anteriores à coleta das amostras com maior isolamento da levedura. Não houve associação significativa entre idade, sexo, raça e comprimento do pelo dos animais estudados com a detecção do FeLV, nem com o isolamento da levedura. Animais domiciliados foram significativamente menos infectados pelo FeLV. Manifestações clínicas e lesões como apatia, desidratação, mucosas pálidas, linfonodos mandibulares aumentados, lesões de pele e mucosa bucal estão associadas significativamente com maior isolamento de Candida albicans e, também, com maior número de gatos FeLV infectados.

Descritores: Candida albicans, FeLV, gatos, corticosteróides, antimicrobianos, imunodepressão, leveduras.

Apresentada: 28 setembro 2001

* Dissertação de Mestrado n.317 (Especialidade: Micologia). 73 f. Programa de Pós-Graduação em Ciências Veterinárias da Faculdade de Veterinária, Porto Alegre - UFRGS. CORRESPONDÊNCIA: L. Ferreiro [e-mail: laerte.ferreiro@ufrgs.br] 


\title{
STUDY OF THE ASSOCIATION BETWEEN THE ISOLATION OF Candida albicans AND THE DETECTION OF THE VIRUS OF FELINE LEUKAEMIA IN CATS IN THE GREATER PORTO ALEGRE REGION**
}

\author{
JOÃO PESSOA RIOGRANDENSE MOREIRA JUNIOR
}

Laerte Ferreiro (Adviser - UFRGS)

\begin{abstract}
Committee:
Luiz Carlos Severo UFRGS

Mario C. A. Meireles UFPel

Sydney Hartz Alves UFSM
\end{abstract}

Candida albicans is an yeast commonly found in the intestinal tract of most mammals and birds. The isolation of this yeast in the skin of healthy animals has been rarely reported in cats however, when the host's defenses are impaired, like immunodeficiency induced by Feline leukaemia virus (FeLV), it is possible the increase of colonization by opportunistic fungi. One hundred and fifty samples were collected (mouth and anal mucosae, haircoat and also blood) from cats of the Porto Alegre region. The samples from the coat and mucosae were cultivated on Sabouraud dextrose agar supplemented with chloramphenicol. Identification of Candida species was based on production of germ tubes and chlamydospores. Candida albicans was the unique specie isolated, being $8.7 \%$ from the oropharyngeal mucosa, $6.7 \%$ from the haircoat, $1.3 \%$ from the rectal mucosa. Blood samples from cats were tested by indirect imunofluorescence (IFA) for evidence of FeLV. Thirty-seven $(24,7 \%)$ cats were seropositive for FeLV. Through the $\chi^{2}$ test also an attempted was made to establish an association between presence of Candida albicans and FeLV detection, as well as with other variables. Also, an attempted was made to establish an association between the FeLV with the same variables. It was found a significant association between cats infected with FeLV and a higher degree of isolation of Candida albicans. The same inference was made between animals wich received antibiotics and corticosteroids within 60 days before to the sample collection and a higher degree of yeast isolation. There were no significant association between age, sex, breed and length of haircoat with FeLV infection, neither with isolation of Candida albicans. According to our results, domestic cats were significantly less infected by FeLV. Clinical signs as apathy, dehydration, pale mucosae, augmented mandibular lymph nodes, oropharyngeal and skin lesions were significantly associated with the higher degree of isolation of Candida albicans, as well as, to a larger number of FeLV positive cats.

Key words: Candida albicans, FeLV, cats, corticosteroids, antibiotics, immunodepression, yeasts.

Presented: 28 september 2001

** Master's Thesis no.317 (Field: Mycology). 73p. Postgraduate Program in Veterinary Sciences, Faculty of Veterinary Medicine, Porto Alegre Federal University of Rio Grande do Sul (UFRGS)/Brazil. CORRESPONDENCE: L. Ferreiro [e-mail: laerte.ferreiro@ufrgs.br] 